\title{
Relevance of Carbon Sequestration to the Physiological and Morphological Traits of Several Green Roof Plants during the First Year after Construction
}

\author{
Takanori Kuronuma ${ }^{1}$, Hitoshi Watanabe ${ }^{2 *}$ \\ ${ }^{1}$ Graduate School of Horticulture, Chiba University, Matsudo, Japan \\ ${ }^{2}$ Center for Environment, Health and Field Sciences, Chiba University, Kashiwa, Japan \\ Email: ^hwatanabe@faculty.chiba-u.jp
}

How to cite this paper: Kuronuma, T. and Watanabe, H. (2017) Relevance of Carbon Sequestration to the Physiological and Morphological Traits of Several Green Roof Plants during the First Year after Construction. American Journal of Plant Sciences, 8 , 14-27.

http://dx.doi.org/10.4236/ajps.2017.81002

Received: October 12, 2016

Accepted: December 23, 2016

Published: December 26, 2016

Copyright $\odot 2017$ by authors and Scientific Research Publishing Inc. This work is licensed under the Creative Commons Attribution International License (CC BY 4.0).

http://creativecommons.org/licenses/by/4.0/

\begin{abstract}
Different vegetation types used for the extensive green roofs have characteristic physiological and morphological traits (e.g., $\mathrm{C}_{3}, \mathrm{C}_{4}$, or CAM photosynthesis, deciduous or evergreen). Several Sedum species are recognized as "inducible CAM" type plants. These differences in the physiological and morphological traits have a considerable effect on the carbon sequestration in the green roofs. The objective of the present study was to quantify the carbon sequestration in several green roof plants during the first year after the construction of the green roofs and to clarify the relevance of the physiological and morphological traits to each plant's ability to sequester carbon in its body using the growth analysis method. We used Zoysia matrella, Ophiopogon japonicus, and Sedum mexicanum species for the study wherein, $S$. mexicanum was assigned to the wet, dry, and non-irrigation treatments, and $Z$. matrella and $O$. japonicus only received the wet treatment. During the first year after the construction, carbon sequestration in the plants and the substrate of $S$. mexicanum was in the range of 276 to $364 \mathrm{~g}-\mathrm{C} / \mathrm{m}^{2} /$ year, which was similar to that of $O$. japonicus and the finding of a previous study. In contrast, $Z$. matrella exhibited the highest carbon sequestration $\left(670 \mathrm{~g}-\mathrm{C} / \mathrm{m}^{2} / \mathrm{year}\right)$, which is also expressed as the relative plant $\mathrm{C}$-sequestration rate per whole-plant $\mathrm{C}$-content $\left(\mathrm{RGR}_{c}\right)$, because $Z$. matrella is a $\mathrm{C}_{4}$ plant and exhibits the highest net assimilation rate $\left(\mathrm{NAR}_{c}\right)$ of all species. Significant differences were not observed in $\mathrm{RGR}_{\mathcal{c}} \mathrm{NAR}_{\mathcal{O}}$ and RMF (root mass fraction) in $S$. mexicanum between the wet and dry treatments. These results suggest that in countries with high rainfall, a high frequency of irrigation has an insignificant effect on the physiological and morphological characteristics, and carbon sequestration in the Sedum green roofs.
\end{abstract}




\section{Keywords}

Growth Analysis, Inducible Type of CAM, Ophiopogon japonicus, Sedum mexicanum, Zoysia matrella

\section{Introduction}

Green roofs are considered an effective technology for solving urban environmental problems. Some of their benefits include mitigation of the urban heatisland effect [1], cooling and insulation of buildings [2] [3], storm water management [4] [5], air pollution reduction [6], habitat provision for other organisms [7], and carbon sequestration [8] [9]. In addition, green roofs are expected to contribute to the improvement of the urban environmental quality of Japan. Kuronuma et al. [10] investigated the temporal changes of carbon content in plants and substrate in rooftop lawns of different ages. Consequently, it was identified that the carbon content in rooftop lawns tends to increase for thirteen years and hence, green roofs are considered a sink for carbon dioxide $\left(\mathrm{CO}_{2}\right)$. These benefits arise from the presence of living plants and the growing medium. In particular, carbon sequestration in green roofs has a direct relationship with the physiological and morphological traits of the vegetation because the plants sequester atmospheric $\mathrm{CO}_{2}$ through photosynthesis, fix carbon, and supply carbon through the litter and root exudates.

Green roofs are classified as either extensive or intensive. The extensive type is characterized by a shallow substrate $(<20 \mathrm{~cm}$ deep) and the requirement of low maintenance. In contrast, the substrate depth of the intensive green roofs is greater than $20 \mathrm{~cm}$ and can support the growth of woody plants. However, an intensive green roof imposes architectural constraints because of its weight; it requires careful maintenance and is costly. Owing to these reasons, the extensive green roof is used almost exclusively in Japan.

The most common types of vegetation used for the extensive green roofs in Japan are the warm-season turf grasses (e.g. Zoysia species) and Sedum species, as they possess physiological and morphological traits that render them suitable for this purpose. For example, warm-season turf grasses are defined as $\mathrm{C}_{4}$ plants whose aboveground parts die in winter. Sedum species are regarded as Crassulacean acid metabolism (CAM) plants whose stomata close during the day and the gas exchange occurs at night [11]. This physiological pathway plays a crucial role during drought stress. In addition, several Sedum species are recognized as "inducible CAM" type [12] [13], which are primarily $\mathrm{C}_{3}$ and $\mathrm{C}_{4}$ plants with the ability to switch their carbon metabolism to the CAM pathway in response to drought stress [14]. Further, some studies suggested that Sedum species on green roofs exhibit the $\mathrm{C}_{3}$ photosynthetic pathway [15] [16]. Such differences in the physiological traits among the vegetation and the physiological responses of the Sedum species to drought stress may have a considerable effect on carbon sequestration in green roofs. However, few studies have been conducted on the re- 
levance of the physiological and morphological traits and carbon sequestration on actual green roofs.

The aim of the present study was to quantify the carbon sequestration potential of several green roof plants during the first year after the construction of green roofs and to elucidate the relevance of the physiological and morphological traits to each plant's ability to sequester carbon in its body. Each plant's ability to sequester carbon in its body was assessed by growth analysis, a widely used analytical model for characterizing plant growth. This model is based on the association between the relative growth rate of the plant (RGR) and the physiological (net assimilation rate-NAR) and morphological (leaf area ratio-LAR) traits [17]; they have the following mathematical relationship:

$$
\mathrm{RGR}=\mathrm{NAR} \times \mathrm{LAR} .
$$

The growth analysis provides a more informative comparison of a plant's relative performance because it can decrease the influence of the initial size and mass of the experimental plants [18]. Although the growth analysis is generally applied to the dry weight of the plant, we focused on the carbon content of the plant and calculated $\mathrm{RGR}_{c}$ (relative plant C-sequestration rate per whole-plant C-content), $\mathrm{NAR}_{c}$ (net assimilation rate), and $\mathrm{LAR}_{c}$ (leaf area ratio per wholeplant C-content). We used $\mathrm{RGR}_{c}$ to represent the plant's ability to sequester carbon in the plant body.

\section{Materials and Methods}

\subsection{Plant Materials}

This study was conducted at the Center for Environment, Health and Field Sciences, Chiba University, Japan. The ground cover herbaceous green roof plants such as Zoysia matrella (L.) Merr. "Kourai-shiba", Ophiopogon japonicus (Thunb.) Ker Gawl. "Tama-Ryu”, and Sedum mexicanum Briton were used for the experiment. The three species are common green roof plants in Japan. $Z$. matrella is a warm-season turf grass and a $\mathrm{C}_{4}$ plant. $O$. japonicus is an evergreen perennial. $S$. mexicanum is one of the most popular Sedum species used for the extensive green roofs in Japan.

All the species were propagated as cuttings in plug flats (128 cells per tray) filled with the seedling propagation soil (Metro Mix; Sun Gro Horticulture, USA). After approximately one month, the plugs were planted in $0.2 \mathrm{~L}$ polyethylene pots $\left(44 \mathrm{~cm}^{2}\right)$ filled to a depth of $5 \mathrm{~cm}$ with commercial artificial soil for green roofs $\left(114 \mathrm{mg} / \mathrm{kgNO}_{3}-\mathrm{N}, 323 \mathrm{mg} / \mathrm{kgNH}_{4}-\mathrm{N}, 159 \mathrm{mg} / \mathrm{kgP}_{2} \mathrm{O}_{5}, 32 \mathrm{mg} / \mathrm{kgK}_{2} \mathrm{O}\right.$, $41 \mathrm{mg} / \mathrm{kgCaO}$, and $2 \mathrm{mg} / \mathrm{kgMgO}$ ), and grown in the greenhouse for two months. The composition of the artificial soil was $75 \%$ perlite, $22 \%$ bark and peat, and $3 \%$ zeolite. Thereafter, they were placed on the rooftop and watered once every two days for three weeks. During this period (September 29, 2014, to October 19, 2014), the minimum temperature was $10.5^{\circ} \mathrm{C}$ and the maximum temperature was $29.1^{\circ} \mathrm{C}$ in Funabashi, Chiba, Japan. 


\subsection{Experimental Design}

Our experiment was carried out for one year. At the start of the experiment on October 20,2014, fifteen pots of all species were sampled over a period of approximately ten days. Green roofs of turf grasses or other perennials are generally installed with irrigation systems to prevent drought stress. In contrast, Sedum green roofs are less often installed because Sedum uses the CAM photosynthetic pathway. In our experiment, $S$. mexicanum was randomly assigned to wet, dry, and non-irrigation treatments after the first sampling. Plants of the wet treatment group were watered once a week from January to March, once every two days from April to June, every day from July to September, and once every two days from October to December. The plants of the dry treatment group were not watered from January to March, and watered once every two weeks from April to June, once a week from July to September, and once every two weeks from October to December. The plants of the non-irrigation treatment group were not watered at any time of the year during the experiment. The wet treatment alone was applied to $Z$. matrella and $O$. japonicas in accordance with the general cultivation practices.

Samplings were carried out every second month (on the $20^{\text {th }}$ of October and December 2014, and the $20^{\text {th }}$ of February, April, June, August, and October 2015) in order to assess the seasonal plant growth subjected to the wet and dry treatments. The plants of the non-irrigation treatment were only harvested at the end of the experiment (October 20, 2015). All treatments additionally received approximately $0.1 \mathrm{~g} /$ pot $\left(20 \mathrm{~g} / \mathrm{m}^{2}\right)$ of controlled-release fertilizer $(8 \mathrm{~N}: 8 \mathrm{P}: 8 \mathrm{~K})$ on June 13 and August 13, 2015, in accordance with the general cultivation practices of the extensive green roofs.

The aboveground biomass, leaf area, and greenness of leaves of all the plants were studied. The aboveground parts were separated into leaves and other non-leaf parts. Leaves were scanned (LP-A500; Epson, Japan) and the image analysis software ImageJ [19] was used to measure the leaf area and leaf greenness. We calculated the leaf area index (LAI: Leaf area per $44 \mathrm{~cm}^{2}$ ) and characterized the leaf greenness using the $G / R$ ratio (green pixels per red pixels in an image of leaves), which is related to the chlorophyll content [20]. The aboveground parts were then dried at $70^{\circ} \mathrm{C}$ for $72 \mathrm{~h}$.

To investigate the morphological traits and the carbon sequestration potential of the plants during the first year after construction, we measured the biomass allocation and the carbon content of the plants and the substrate. At the start and end of the experiment, all the fifteen plants were separated into leaves, stems, roots, flowers, and substrate. They were dried at $70^{\circ} \mathrm{C}$ for $72 \mathrm{~h}$. The biomass allocation was analyzed using five indices: the leaf mass fraction (LMF; leaf mass per whole-plant mass), stem mass fraction (SMF; stem mass per wholeplant mass), root mass fraction (RMF; root mass per whole-plant mass), flower mass fraction (FMF; flower mass per whole-plant mass), and specific leaf area (SLA; leaf area per leaf mass). The carbon and nitrogen concentrations were measured using an organic elemental analyzer (2400 Series II CHNS/O System; 
PerkinElmer, USA). The carbon content was quantified by multiplying the carbon concentration and the dry weight. Carbon sequestration was calculated by subtracting the plant and substrate carbon content in October 2014 from the values in October 2015.

\subsection{Growth Analysis}

We employed the fundamental growth analysis equations, which was the classical approach [18]. The paring method was also used [21], ranking the plants at harvest according to their carbon content. The values of $\mathrm{RGR}_{c} \mathrm{NAR}_{c}$ and $\mathrm{LAR}_{c}$ were calculated for each pair of the same rank between both the harvests. These indices were defined as

$$
\begin{aligned}
\operatorname{RGR}_{c} & =\frac{\log _{e} W_{c 2}-\log _{e} W_{c 1}}{T_{2}-T_{1}} \\
\mathrm{NAR}_{c} & =\frac{W_{c 2}-W_{c 1}}{T_{2}-T_{1}} \times \frac{\log _{e} L_{A 2}-\log _{e} L_{A 1}}{L_{A 2}-L_{A 1}} \\
\mathrm{LAR}_{c} & =\frac{L_{A 1} / W_{c 1}+L_{A 2} / W_{c 2}}{2}
\end{aligned}
$$

where $W_{c 1}$ and $W_{c 2}$ are the plant carbon contents, and $L_{A 1}$ and $L_{A 2}$ are the total leaf areas of the plants at times $T_{1}$ and $T_{2}$, respectively. In this experiment, $T_{1}$ and $T_{2}$ correspond to October 20,2014, and October 20, 2015, respectively.

\subsection{Statistical Analysis}

Data were analyzed using IBM SPSS Statistics version 22.0 (IBM Japan, Japan). ANOVA was used to assess the effect of the treatments and the plant species. Differences in the mean values were assessed with Student's $t$-test or multiple comparisons (Tukey-b with homoscedasticity assumed, Dinnett-T3 with homoscedasticity not assumed).

\section{Results}

The values for ambient air temperature and precipitation in Funabashi, Chiba, Japan, are shown in Figure 1(a) and Figure 1(b). These values were obtained from the database of the Japan Meteorological Agency. The monthly mean daily temperatures in summer (July and August) exceeded $25^{\circ} \mathrm{C}$. The monthly minimum temperatures from December 2014 to March 2015 were below $0^{\circ} \mathrm{C}$ and the monthly maximum temperatures from May to September 2015 exceeded $30^{\circ} \mathrm{C}$.

The maximum monthly total precipitation is September was $385 \mathrm{~mm}$, while that in May and October 2015 was approximately $50 \mathrm{~mm}$ (Figure 1(b)). The annual total precipitation was $1521 \mathrm{~mm}$ (November 1, 2014, to October 31, 2015). The number of days with rain in summer was greater than 15 , and the annual number of days with rain was 180 days. During the experiment, the longest periods when there was no rain in the non-irrigation treatment was from April 23 to May 11, 2015. The longest period when there was no rain or irrigation in the dry treatment was from April 23 to May 3, 2015. 


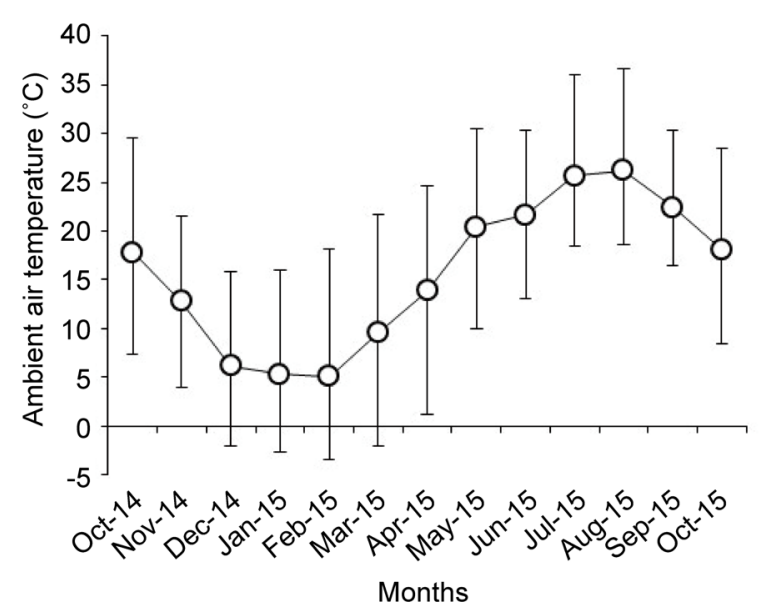

(a)

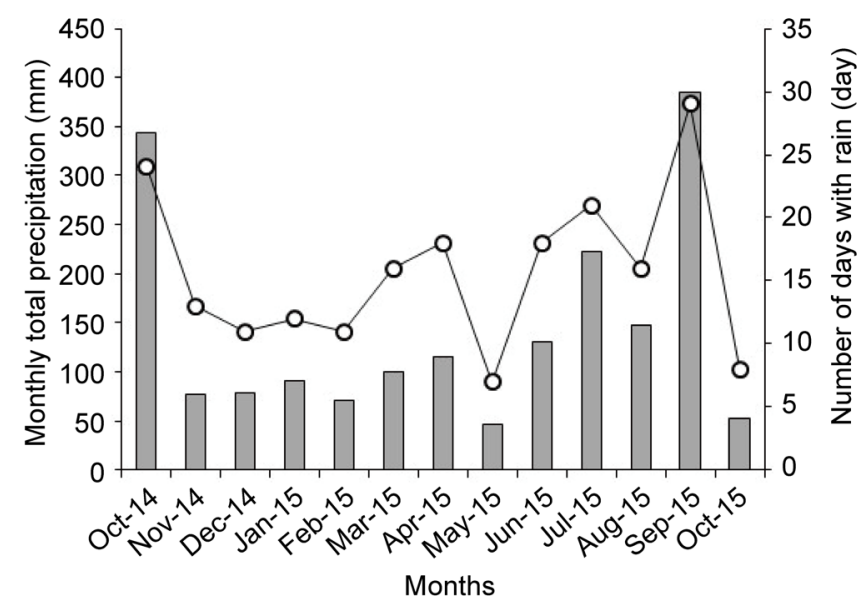

(b)

Figure 1. The ambient air temperature (a), and the monthly total precipitation and the number of days with rain (b) in Funabashi, Chiba. (a): The line represents the monthly mean daily temperature. The vertical bars indicate the monthly maximum and minimum temperatures. (b): The bar graph indicates the monthly total precipitation. The line indicates the number of days with rain.

\subsection{Plants' Status}

The time course of the aboveground biomass is shown in Figure 2(a) and the average aboveground biomass of all the species increased from the fourth sampling (April 20, 2015) onwards. At the end of the experiment, S. mexicanum in the wet treatment exhibited the highest aboveground biomass, and $O$. japonicus exhibited the lowest among all the species.

The time course of LAI was similar to the aboveground biomass except for $S$. mexicanum in the dry treatment (Figure 2(b)). LAI values from $S$. mexicanum in the dry treatment significantly decreased from the sixth sampling (August 20, 2015) onwards. At the end of the experiment, $Z$. matrella displayed the lowest LAI among all the species.

$S$. mexicanum in the wet treatment showed a significantly higher aboveground biomass and LAI on August 20, 2015, than that in the dry treatment. However, at the end of the experiment, there were no significant differences between the treatments.

The G/R ratio of $O$. japonicus was significantly higher than that in the other species during the entire experimental period, except at the fifth sampling (Table 1 ). Moreover, only $O$. japonicus had a G/R value greater than 1.0 during the experimental period.

All the three measurements of $S$. mexicanum in the non-irrigation treatment were lower than those of the wet and dry treatments at the end of the experiment (non-irrigation treatment: above ground biomass $=1.71 \pm 0.09 \mathrm{~g}, \mathrm{LAI}=4.65 \pm$ $0.22, \mathrm{G} / \mathrm{R}=0.91 \pm 0.00)$.

\subsection{Biomass Allocation}

The morphological traits of all the species under each treatment on October 20, 2015, are presented in Table 2. Flowering was not observed in any species under 


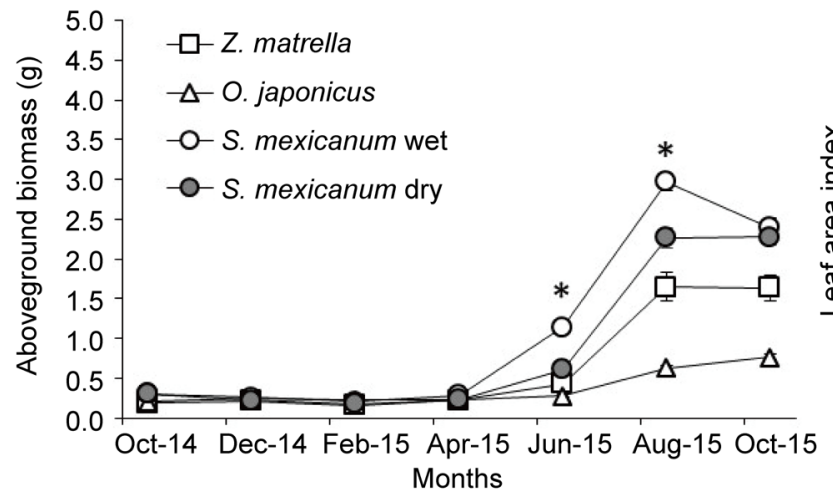

(a)

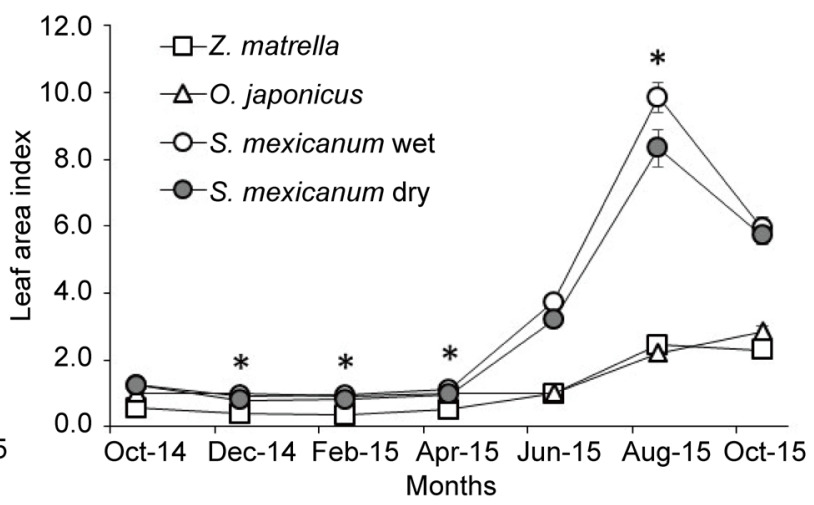

(b)

Figure 2. Time course of the aboveground biomass (a) and LAI (b) of the three green roof plants. Means \pm SE are presented ( $\mathrm{n}=$ 15). ${ }^{\star}$ Represents significant differences between the wet and the dry treatments of $S$. mexicanum (Student's t-test: ${ }^{\star} \mathrm{P}<0.05$ ).

Table 1. Time course of the mean values of $G / R$ of the three green roof plants.

\begin{tabular}{|c|c|c|c|c|c|c|c|c|c|c|c|}
\hline \multicolumn{2}{|c|}{ Species and treatment } & \multicolumn{4}{|c|}{ Oct-14 } & \multirow{2}{*}{$\begin{array}{r}\text { Dec-14 } \\
0.94 \pm 0.00\end{array}$} & \multirow{2}{*}{$\frac{\text { Feb-15 }}{b^{y} 0.96 \pm 0.00 b^{y}}$} & \multirow{2}{*}{$\begin{array}{r}\text { Apr-15 } \\
1.03 \pm 0.00\end{array}$} & \multirow{2}{*}{$\begin{array}{c}\text { Jun-15 } \\
b^{y} 1.14 \pm 0.01 c^{y}\end{array}$} & \multirow{2}{*}{$\frac{\text { Aug-15 }}{y^{y} 1.10 \pm 0.01 c^{y}}$} & \multirow{2}{*}{$\frac{\text { Oct-15 }}{1.02 \pm 0.01 b^{y}}$} \\
\hline Z. matrella & Wet & 1.15 & \pm & 0.00 & $b^{z}$ & & & & & & \\
\hline O. japonicus & Wet & 1.21 & \pm & 0.00 & c & $1.16 \pm 0.00$ & c $1.06 \pm 0.01 \mathrm{c}$ & $=1.06 \pm 0.01$ & c $1.11 \pm 0.00 \mathrm{~b}$ & $1.19 \pm 0.00 \mathrm{~d}$ & d $1.18 \pm 0.00 c$ \\
\hline S. mexicanum & $\begin{array}{l}\text { Wet } \\
\text { Dry }\end{array}$ & 1.04 & \pm & 0.01 & $\mathrm{a}$ & $\begin{array}{l}0.91 \pm 0.00 \\
0.91 \pm 0.00\end{array}$ & $\begin{array}{l}\text { a } 0.92 \pm 0.00 \mathrm{a} \\
\text { a } 0.92 \pm 0.00 \mathrm{a}\end{array}$ & $\begin{array}{l}1.02 \pm 0.00 \\
1.01 \pm 0.00\end{array}$ & $\begin{array}{l}\text { ab } 1.08 \pm 0.01 \mathrm{a} \\
\text { a } 1.11 \pm 0.01 \mathrm{~b}\end{array}$ & $\begin{array}{l}1.04 \pm 0.01 b \\
0.95 \pm 0.01 \mathrm{a}\end{array}$ & $\begin{array}{l}\text { b } 1.03 \pm 0.01 b \\
\text { a } 0.93 \pm 0.00 a\end{array}$ \\
\hline
\end{tabular}

Data represented by Mean $\pm \mathrm{SE}(\mathrm{n}=15) .{ }^{\mathrm{z}}$ Significant differences among the means are indicated by different letters based on Dunnett-T3 at $\mathrm{P}<0.05 .{ }^{\mathrm{y}} \mathrm{Signi}-$ ficant differences among the means are indicated by different letters based on Tukey-b test at $\mathrm{P}<0.05$.

Table 2. Mean values for the biomass allocation as measured by the leaf mass fraction (LMF), stem mass fraction (SMF), root mass fraction (RMF), and specific leaf area (SLA) of the three green roof plants at the end of the experiment.

\begin{tabular}{|c|c|c|c|c|c|c|c|c|c|c|c|c|c|c|c|c|c|}
\hline \multicolumn{2}{|c|}{ Species and treatment } & \multicolumn{4}{|c|}{ LMF } & \multicolumn{4}{|c|}{ SMF } & \multicolumn{4}{|c|}{ RMF } & \multicolumn{4}{|c|}{$\operatorname{SLA}\left(\mathrm{m}^{2} / \mathrm{g}\right)$} \\
\hline Z. matrella & Wet & 0.11 & \pm & 0.00 & $a^{z}$ & 0.70 & \pm & 0.01 & $\mathrm{~d}^{\mathrm{y}}$ & 0.19 & \pm & 0.01 & $a^{y}$ & 0.016 & \pm & 0.000 & \\
\hline O. japonicus & Wet & 0.22 & \pm & 0.01 & $\mathrm{~b}$ & 0.17 & \pm & 0.01 & $\mathrm{a}$ & 0.61 & \pm & 0.02 & $\mathrm{~d}$ & 0.017 & \pm & 0.001 & \\
\hline \multirow[t]{3}{*}{ S. mexicanum } & Wet & 0.48 & \pm & 0.02 & $c$ & 0.28 & \pm & 0.01 & c & 0.23 & \pm & 0.02 & $a b$ & 0.016 & \pm & 0.000 & n.s. ${ }^{y}$ \\
\hline & Dry & 0.48 & \pm & 0.01 & c & 0.24 & \pm & 0.01 & $\mathrm{~b}$ & 0.28 & \pm & 0.01 & $\mathrm{bc}$ & 0.016 & \pm & 0.000 & \\
\hline & Non & 0.46 & \pm & 0.01 & $c$ & 0.21 & \pm & 0.01 & $\mathrm{~b}$ & 0.33 & \pm & 0.02 & c & 0.017 & \pm & 0.001 & \\
\hline
\end{tabular}

Data represented by Mean \pm SE $(n=15) .{ }^{2}$ Significant differences among the means are indicated by different letters based on Dunnett-T3 at $\mathrm{P}<0.05 .{ }^{\mathrm{y}}$ Significant differences among the means are indicated by different letters based on Tukey-b test at $\mathrm{P}<0.05$.

any treatment, at the end of the experiment. The SMF of $Z$. matrella was significantly higher than that of $O$. japonicus and $S$. mexicanum, which indicates that $Z$. matrella allocated significantly more biomass to the stems than did the other species. Likewise, the LMF and RMF values clearly demonstrate that $S$. mexicanum allocated significantly more biomass to the leaves, and $O$. japonicus allocated significantly more biomass to the roots.

S. mexicanum did not exhibit significant differences in the LMF and SLA values among the treatments (Table 2). However, the SMF in the wet treatment was significantly higher than that in the dry and non-irrigation treatments, and the 
RMF in the wet treatment was significantly lower than that in the non-irrigation treatment.

\subsection{The Plant and Substrate Nitrogen Concentrations}

The plant and substrate nitrogen concentrations at the end of the experiment (October, 20 2015) are shown in Table 3. O. japonicus exhibited the highest plant nitrogen concentration among all the species. $S$. mexicanum did not exhibit any significant difference in plant nitrogen concentration among the treatments. There were no significant differences in substrate nitrogen concentration among the species and treatments.

\subsection{The Plant Carbon Content}

The dry weight, carbon concentration, and carbon content of the plants on October 20, 2014, and 2015 are shown in Table 4. The plant dry weight at the end of the experiment was significantly higher than that at the start of the experiment among all the species and treatments. The dry weight of $S$. mexicanum under the wet treatment was not significantly different from that under the dry treatment, whereas it was significantly higher than that under the non-irrigation treatment.

Table 3. Mean values for the plant and substrate nitrogen concentrations of the three green roof plants at the end of the experiment.

\begin{tabular}{|c|c|c|c|c|c|c|c|c|c|}
\hline \multicolumn{2}{|c|}{ Species and treatment } & \multicolumn{4}{|c|}{ Plant nitrogen concentration (\%) } & \multicolumn{4}{|c|}{ Substrate nitrogen concentration (\%) } \\
\hline Z. matrella & Wet & 0.77 & \pm & 0.05 & $\mathrm{~b}^{\mathrm{z}}$ & 0.29 & \pm & 0.01 & \\
\hline O. japonicus & Wet & 1.05 & \pm & 0.02 & c & 0.27 & \pm & 0.01 & \\
\hline \multirow[t]{3}{*}{ S. mexicanum } & Wet & 0.65 & \pm & 0.02 & a & 0.28 & \pm & 0.01 & n.s. ${ }^{y}$ \\
\hline & Dry & 0.65 & \pm & 0.02 & $\mathrm{a}$ & 0.29 & \pm & 0.01 & \\
\hline & Non & 0.66 & \pm & 0.01 & $\mathrm{a}$ & 0.28 & \pm & 0.02 & \\
\hline
\end{tabular}

Data represented by Mean \pm SE $(n=15) .{ }^{\mathrm{z}}$ Significant differences among the means are indicated by different letters based on Tukey-b test at $\mathrm{P}<0.05$. ${ }^{\mathrm{y}}$ Significant differences among the means are indicated by different letters based on Dunnett-T3 at $\mathrm{P}<0.05$.

Table 4. Mean values for the plant dry weight, carbon concentration, and carbon content of the three green roof plants at the start and end of the experiment.

\begin{tabular}{|c|c|c|c|c|c|c|c|c|c|c|c|c|c|c|c|c|c|c|c|c|c|c|c|}
\hline \multirow{2}{*}{\multicolumn{2}{|c|}{$\begin{array}{l}\text { Species and } \\
\text { treatment }\end{array}$}} & \multicolumn{7}{|c|}{ Plant dry weight (g/pot) } & \multicolumn{8}{|c|}{ Plant carbon concentration (\%) } & \multicolumn{7}{|c|}{ Plant carbon content $\quad(g-C / p o t)$} \\
\hline & & \multicolumn{3}{|c|}{ Oct-14 } & \multicolumn{4}{|c|}{ Oct-15 } & \multicolumn{3}{|c|}{ Oct-14 } & \multicolumn{5}{|c|}{ Oct-15 } & \multicolumn{3}{|c|}{ Oct-14 } & \multicolumn{4}{|c|}{ Oct-15 } \\
\hline Z. matrella & Wet & 0.41 & \pm & 0.02 & 5.80 & \pm & 0.33 & $*-$ & 41.9 & \pm & 0.7 & 43.2 & \pm & 0.3 & & $c^{z}$ & 0.17 & \pm & 0.01 & 2.50 & \pm & 0.14 & * \\
\hline O. japonicus & Wet & 0.51 & \pm & 0.03 & 3.36 & \pm & 0.11 & * - & 41.3 & \pm & 0.4 & 40.9 & \pm & 0.3 & & $\mathrm{~b}$ & 0.21 & \pm & 0.01 & 1.37 & \pm & 0.05 & * \\
\hline \multirow[t]{3}{*}{ S. mexicanum } & Wet & & & & 3.40 & \pm & 0.18 & $* \mathrm{~B}^{\mathrm{z}}$ & & & & 36.6 & \pm & 0.3 & * & $\mathrm{a}$ & & & & 1.24 & \pm & 0.07 & * $\mathrm{B}$ \\
\hline & Dry & 0.47 & \pm & 0.03 & 3.37 & \pm & 0.12 & * $\mathrm{B}$ & 33.6 & \pm & 0.8 & 37.0 & \pm & 0.4 & * & $\mathrm{a}$ & 0.16 & \pm & 0.01 & 1.25 & \pm & 0.04 & * $\mathrm{B}$ \\
\hline & Non & & & & 2.70 & \pm & 0.11 & * A & & & & 36.8 & \pm & 0.4 & * & $\mathrm{a}$ & & & & 0.99 & \pm & 0.04 & * A \\
\hline
\end{tabular}

Data represented by Mean \pm SE $(\mathrm{n}=15)$. ${ }^{\star}$ Represents significant differences between the results of October 2014 and October 2015 (Student's $\mathrm{t}$-test: ${ }^{\star} \mathrm{P}<$ 0.05). ${ }^{\mathrm{z}}$ Significant differences among the means are indicated by different letters based on Tukey-b test at $\mathrm{P}<0.05$. 
The highest carbon concentration of the three species was observed in Z. matrella (Table 4). However, no significant differences were observed in the carbon concentration of $S$. mexicanum among the treatments.

The carbon content of the plants among all the species and treatments was significantly increased during the experimental period (Table 4). No significant differences were observed in the carbon content of $S$. mexicanum under the wet and dry treatments; however, it was significantly higher than that under the nonirrigation treatment.

\subsection{The Substrate Carbon Content and Total Carbon Sequestration for One Year}

The substrate dry weight, carbon concentration, and carbon content on October 20, 2014, and 2015 are shown in Table 5. At the end of the experiment, only $Z$. matrella exhibited a higher substrate dry weight than that at the start of the experiment. The substrate dry weights of $O$. japonicus and $S$. mexicanum decreased slightly during the experiment.

$Z$. matrella and $S$. mexicanum exhibited a significant increase in the substrate carbon concentration and content during the experimental period (Table 5). In contrast, $O$. japonicus did not exhibit any significant differences in these characteristics between October 2014 and October 2015. S. mexicanum exhibited no significant differences in the substrate dry weight, carbon concentration, and carbon content among the treatments.

The total carbon content and the annual carbon sequestration are shown in Table 6. The total carbon content significantly increased during the experimental period among all the species and treatments. It was not significantly different in $S$. mexicanum under the wet and dry treatments, whereas it was significantly higher in the non-irrigation treatment.

During the first year after construction of the green roofs, the carbon sequestration potential of $Z$. matrella was the highest among all the species (Table 6). S. mexicanum under the non-irrigation treatment exhibited the lowest carbon sequestration potential and was similar to that of $O$. japonicus.

Table 5. Mean values for the substrate dry weight, carbon concentration, and carbon content of the three green roof plants at the start and end of the experiment.

\begin{tabular}{|c|c|c|c|c|c|c|c|c|c|c|c|c|c|c|c|c|c|c|}
\hline \multirow{2}{*}{\multicolumn{2}{|c|}{$\begin{array}{l}\text { Species and } \\
\text { treatment }\end{array}$}} & \multicolumn{6}{|c|}{ Substrate dry weight (g/pot) } & \multicolumn{5}{|c|}{ Substrate carbon concentration (\%) } & \multicolumn{6}{|c|}{ Substrate carbon content (g-C/pot) } \\
\hline & & \multicolumn{3}{|c|}{ Oct-14 } & \multicolumn{3}{|c|}{ Oct-15 } & \multicolumn{3}{|c|}{ Oct-14 } & \multicolumn{2}{|r|}{ Oct-15 } & \multicolumn{3}{|c|}{ Oct-14 } & \multicolumn{3}{|c|}{ Oct-15 } \\
\hline Z. matrella & Wet & 31.8 & \pm & 0.2 & 33.2 & \pm 0.4 * & - & 5.6 & \pm & 0.1 & 7.2 & $\pm 0.5 *$ & 1.77 & \pm & 0.03 & 2.39 & $\pm 0.12 *$ & ${ }^{*}-$ \\
\hline O. japonicus & Wet & 29.1 & \pm & 0.3 & 28.2 & \pm 0.5 & - & 5.4 & \pm & 0.2 & 6.0 & \pm 0.4 & 1.59 & \pm & 0.04 & 1.69 & \pm 0.06 & - \\
\hline \multirow[t]{3}{*}{ S. mexicanum } & Wet & & & & 29.7 & \pm 0.6 & & & & & 6.5 & $\pm 0.3 *$ n.s. $^{2}$ & & & & 1.94 & \pm 0.07 * & * \\
\hline & Dry & 30.5 & \pm & 0.3 & 29.8 & \pm 0.6 & $\begin{array}{c}\text { n.s. } \\
z\end{array}$ & 5.0 & \pm & 0.2 & 6.9 & $\pm 0.3 *$ & 1.54 & \pm & 0.03 & 2.06 & \pm 0.04 * & ${ }^{*}$ n.s. ${ }^{y}$ \\
\hline & Non & & & & 30.4 & \pm 0.3 & & & & & 6.2 & $\pm 0.4 *$ & & & & 1.92 & $\pm 0.09 *$ & * \\
\hline
\end{tabular}

Data represented by Mean \pm SE $(n=15)$. ${ }^{*}$ Represents significant differences between the results of October 2014 and October 2015 (Student's $\mathrm{t}$-test: ${ }^{*} \mathrm{P}<$

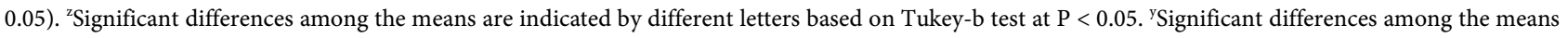
are indicated by different letters based on Dunnett-T3 at $\mathrm{P}<0.05$. 
Table 6. Mean values for the total carbon content at the start and end of the experiment and carbon sequestration of the three green roof plants during the first year after construction.

\begin{tabular}{|c|c|c|c|c|c|c|c|c|c|c|}
\hline \multirow{2}{*}{\multicolumn{2}{|c|}{ Species and treatment }} & \multicolumn{8}{|c|}{ Total carbon content (g-C/pot) } & \multirow{3}{*}{$\begin{array}{c}\text { Carbon sequestration } \\
\text { (g-C/pot/year) } \\
2.95\end{array}$} \\
\hline & & \multicolumn{3}{|c|}{ Oct-14 } & \multicolumn{5}{|c|}{ Oct-15 } & \\
\hline Z. matrella & Wet & 1.95 & \pm & 0.03 & 4.89 & \pm & 0.15 & * & - & \\
\hline O. japonicus & Wet & 1.80 & \pm & 0.05 & 3.04 & \pm & 0.09 & * & - & 1.24 \\
\hline \multirow[t]{3}{*}{ S. mexicanum } & Wet & & & & 3.18 & \pm & 0.07 & * & $\mathrm{AB}^{\mathrm{z}}$ & 1.48 \\
\hline & Dry & 1.70 & \pm & 0.02 & 3.30 & \pm & 0.09 & * & B & 1.60 \\
\hline & Non & & & & 2.92 & \pm & 0.10 & * & A & 1.21 \\
\hline
\end{tabular}

Data represented by Mean \pm SE $(n=15) .{ }^{*}$ Represents significant differences between the results of October 2014 and October 2015 (Student's t-test: ${ }^{*} \mathrm{P}<$ 0.05). ${ }^{\mathrm{Z}}$ Significant differences among the means are indicated by different letters based on Tukey-b test at $\mathrm{P}<0.05$.

\subsection{The Ability of Each Plant to Sequester Carbon in the Plant Body}

The growth analysis applied to the plant carbon contents is presented in Table 7. Although $Z$. materella exhibited the lowest $\mathrm{LAR}_{c}$ among all the species, its $\mathrm{NAR}_{c}$ was more than twice that of the others. Consequently, $Z$. matrella had the highest $\mathrm{RGR}_{c} S$. mexicanum exhibited the lowest $\mathrm{NAR}_{c}$ and the highest $\mathrm{LAR}_{c}$ in this experiment, which resulted in its $\mathrm{RGR}_{c}$ being similar to that of $O$. japonicus.

There were no significant differences in the $\mathrm{NAR}_{c}$ and $\mathrm{LAR}_{c}$ values of $S$. mexicanum among the treatments. However, the non-irrigation treatment resulted in lower $\mathrm{RGR}_{c}$ values than by the other treatments.

\section{Discussion}

\subsection{Carbon Sequestration in Several Green Roof Plants during the First Year after Construction}

During the first year after the construction of the green roofs, carbon sequestration of the three species is represented as grams of carbon per $\mathrm{m}^{2}$ per year (Table 6) as Z. matrella: $670 \mathrm{~g}-\mathrm{C} / \mathrm{m}^{2} /$ year, O. japonicus: $282 \mathrm{~g}-\mathrm{C} / \mathrm{m}^{2} /$ year, $S$. mexicanum: $336 \mathrm{~g}-\mathrm{C} / \mathrm{m}^{2} /$ year in the wet treatment, $S$. mexicanum in the dry and nonirrigation treatments was 364 and $276 \mathrm{~g}-\mathrm{C} / \mathrm{m}^{2} /$ year, respectively. Getter et al. [8] demonstrated that the Sedum green roofs sequester $375 \mathrm{~g}-\mathrm{C} / \mathrm{m}^{2} /$ year in the plants and the substrates for two years after construction, which is similar to our results from $S$. mexicanum. Accordingly, this study reiterates the carbon sequestration capacity of several green roof plants and suggests that the warm-season turf grasses are effective choices from the standpoint of carbon sequestration in green roofs.

\subsection{Carbon Accumulation in the Substrate}

S. mexicanum receiving the wet treatment exhibited significantly higher aboveground biomass and LAI than it did under the dry treatment in summer (August 20, 2015), whereas at the end of the experiment, there were no significant differences (Figure 2(a), Figure 2(b)). Moreover, the substrate dry weight, carbon concentration, and carbon content under the wet treatment were not 
Table 7. Mean values for $\mathrm{RGR}_{c}$ (relative plant C-sequestration rate per whole-plant C-content), $\mathrm{NAR}_{c}$ (net assimilation rate), and $\mathrm{LAR}_{c}$ (leaf area ratio per whole-plant C-content) of the three green roof plants.

\begin{tabular}{|c|c|c|c|c|c|c|c|c|c|c|c|c|c|}
\hline \multirow{2}{*}{\multicolumn{2}{|c|}{ Species and treatment }} & \multicolumn{4}{|c|}{$\mathrm{RGR}_{c}$} & \multicolumn{4}{|c|}{$\mathrm{NAR}_{c}$} & \multicolumn{4}{|c|}{$\mathrm{LAR}_{c}$} \\
\hline & & \multicolumn{4}{|c|}{$\left(\right.$ day $\left.^{-1}\right)$} & \multicolumn{4}{|c|}{ (g-C/m²/day) } & \multicolumn{4}{|c|}{$\left(\mathrm{m}^{2} / \mathrm{g}-\mathrm{C}\right)$} \\
\hline Z. matrella & Wet & 0.0074 & \pm & 0.0001 & $c^{2}$ & 1.38 & \pm & 0.06 & $c^{y}$ & 0.0094 & \pm & 0.0005 & $a^{z}$ \\
\hline O. japonicus & Wet & 0.0052 & \pm & 0.0001 & $\mathrm{a}$ & 0.54 & \pm & 0.04 & $\mathrm{~b}$ & 0.0155 & \pm & 0.0006 & $\mathrm{~b}$ \\
\hline \multirow[t]{3}{*}{ S. mexicanum } & Wet & 0.0056 & \pm & 0.0000 & $\mathrm{~b}$ & 0.26 & \pm & 0.01 & $\mathrm{a}$ & 0.0281 & \pm & 0.0010 & c \\
\hline & Dry & 0.0057 & \pm & 0.0001 & $\mathrm{~b}$ & 0.27 & \pm & 0.01 & $\mathrm{a}$ & 0.0277 & \pm & 0.0009 & c \\
\hline & Non & 0.0050 & \pm & 0.0001 & $\mathrm{a}$ & 0.24 & \pm & 0.01 & $\mathrm{a}$ & 0.0280 & \pm & 0.0011 & c \\
\hline
\end{tabular}

Data represented by Mean $\pm \mathrm{SE}(\mathrm{n}=15) .{ }^{\mathrm{Z}}$ Significant differences among the means are indicated by different letters based on Tukey-b test at $\mathrm{P}<0.05 .{ }^{\mathrm{y}}$ Significant differences among the means are indicated by different letters based on Dunnett-T3 at $\mathrm{P}<0.05$.

significantly higher than that under the dry treatment (Table 5). These results suggest that the aboveground parts of $S$. mexicanum in the wet treatment were mostly dispersed by winds from summer to autumn.

However, the substrate carbon contents of $Z$. matrella and $S$. mexicanum in all treatments significantly increased during the experimental period, while their $\mathrm{G} / \mathrm{R}$ values were below 1.0 in winter (Table 1 , Table 5). In contrast, $O$. japonicus maintained the greenness of its leaves green during the experimental period, whereas its substrate carbon content and concentration did not increase significantly. Although a vegetation of evergreen plants could add an aesthetic value to a green roof throughout the year, our results suggested that carbon accumulation in the substrate of the deciduous green roof plants is greater than that of evergreen plants.

\subsection{Relevance of the Physiological and Morphological Traits and the Ability to Sequester Carbon in the Plant Body}

A significant correlation $(\mathrm{r}=0.97 ; \mathrm{P}<0.01)$ was observed between $\mathrm{RGR}_{c}$ and carbon sequestration in the plant body during the experimental period for all species and treatments (Table 4, Table 7). In addition, LAR is known to be an index derived from LMF and SLA, and our results indicated a significant correlation $(\mathrm{r}=0.99 ; \mathrm{P}<0.01)$ between $\mathrm{LAR}_{c}$ and the product of LMF and SLA (Table 2, Table 7). The $\mathrm{LAR}_{c}$ of $Z$. matrella was the lowest among all the species because LMF was significantly lower in this species than in the others (Table 2, Table 7). However, the photosynthetic rate of the $\mathrm{C}_{4}$ plants is generally higher than that of the $\mathrm{C}_{3}$ and CAM plants; accordingly, Z. matrella would show the highest $\mathrm{NAR}_{c}$ and $\mathrm{RGR}_{c}$. Therefore, our results suggest that applying the growth analysis to the assessment of the plant carbon content could reveal the relevance of physiological $\left(\mathrm{NAR}_{c}\right)$ and morphological $\left(\mathrm{LAR}_{c}\right)$ traits to the ability to sequester carbon in the plant body $\left(\mathrm{RGR}_{c}\right)$.

A previous study carried out under a controlled environmental system demonstrated that $S$. mexicanum in a wet and an increased nutrient condition exhibited the $\mathrm{C}_{3}$ photosynthetic pathway and its $\mathrm{LAR}_{c}$ was greater than triple that of $Z$. matrella. Further, these physiological and morphological responses of $S$. mex- 
icanum have led to a higher $\mathrm{RGR}_{c}$ than that of $Z$. matrella and their drought treatments [22]. However, there were no significant differences in LMF, SLA, $\mathrm{NAR}_{\mathcal{c}}$ or $\mathrm{LAR}_{c}$ of $S$. mexicanum among the treatments (Table 2, Table 7). Consequently, $\mathrm{RGR}_{c}$ of $S$. mexicanum under the wet treatment was lower than that of $Z$. matrella, and there was no significant difference between that under the wet and dry treatments (Table 7). A large rainfall and a poor nutrient condition in this experiment were considered to cause this distinction. It is well documented that plants respond to a decrease in belowground resources (e.g., water, nutrients) with an increase in the biomass allocation to the roots [23]. However, there were no significant differences in RMF between the wet and dry treatments (Table 2). This result suggests that drought stress in the dry treatment was reduced by a high rainfall and a large number of days with rain (Figure 1(b)). In addition, several studies have proved that the whole-plant and leaf $\mathrm{N}$ concentration have significant correlations with RGR and NAR [24] [25], whereas our results indicated a whole-plant $\mathrm{N}$ concentration that was below 1.0 in all treatments without any significant differences among them (Table 3). Thus, although the substrate retained water in the wet treatment, poor nutrient conditions may have prevented the plant growth.

Therefore, it is clear that in countries with high rainfall, a high frequency of irrigation has little effect on the physiological and morphological characteristics and carbon sequestration in the Sedum green roofs. Therefore, it is necessary to consider the maintenance practices, for example, fertilizer management, which will enable effectiveness of the Sedum green roofs.

In this study, although we focused on carbon sequestration during the first year after the construction of the green roofs, the carbon balance would reach equilibrium where the decomposition of organic matter equaled the sequestration. However, our method of applying the growth analysis to the assessment of the plant carbon content will contribute to the understanding of the relevance of carbon sequestration to the growth of the green roof plants.

\section{Conclusions}

Our results demonstrated the carbon sequestration capacity of several green roof plants during the first year after construction, which suggests that the warmseason turf grasses are effective choices because of their high $\mathrm{NAR}_{c}$ and $\mathrm{RGR}_{c}$

In addition, the growth analysis of the plant carbon content enabled us to understand the relevance of the physiological and morphological traits of plants to the ability to sequester carbon in their body. This would support the selection of plants with higher capacities for carbon sequestration, and aid the employment of maintenance practices that increase $\mathrm{NAR}_{c}$ and $\mathrm{LAR}_{c}$. We believe that our results would contribute to the development of more appropriate designs and maintenance for each green roof.

\section{References}

[1] Susca, T., Gaffin, S.R. and Dell'Osso, G.R. (2011) Positive Effects of Vegetation: 
Urban Heat Island and Green Roofs. Environmental Pollution, 159, 2119-2126. https://doi.org/10.1016/j.envpol.2011.03.007

[2] Sailor, D.J. (2008) A Green Roof Model for Building Energy Simulation Programs. Energy and Buildings, 40, 1466-1478. https://doi.org/10.1016/j.enbuild.2008.02.001

[3] Wong, N.H., Cheong, D.K.W., Yan, H., Soh, J., Ong, C.L. and Sia, A. (2003) The Effects of Rooftop Garden on Energy Consumption of a Commercial Building in Singapore. Energy and Buildings, 35, 353-364. https://doi.org/10.1016/S0378-7788(02)00108-1

[4] Getter, K.L., Rowe, D.B. and Andresen, J.A. (2007) Quantifying the Effect of Slope on Extensive Green Roof Stormwater Retention. Ecological Engineering, 31, 225 231. https://doi.org/10.1016/j.ecoleng.2007.06.004

[5] Villarreal, E.L. and Bengstsson, L. (2005) Response of Sedum Green-Roof to Individual Rain Events. Ecological Engineering, 25, 1-7. https://doi.org/10.1016/j.ecoleng.2004.11.008

[6] Yan, J., Yu, Q. and Gong, P. (2008) Quantifying Air Pollution Removal by Green Roofs in Chicago. Atmospheric Environment, 42, 7266-7273.

https://doi.org/10.1016/j.atmosenv.2008.07.003

[7] Kadas, G. (2006) Rare Invertebrates Colonizing Green Roofs in London. Urban Habitats, 4, 66-86.

[8] Getter, K.L., Rowe, D.B. and Robertson, G.P. (2009) Carbon Sequestration Potential of Extensive Green Roofs. Environmental Science \& Technology, 43, 7564-7570. https://doi.org/10.1021/es901539x

[9] Ondoño, S., Martínez-Sánchez, J.J. and Moreno, J.L. (2016) The Composition and Depth of Green Roof Substrates Affect the Growth of Silene vulgaris and Lagurus ovatus Species and the $\mathrm{C}$ and $\mathrm{N}$ Sequestration under Two Irrigation Conditions. Journal of Environmental Management, 166, 330-340.

https://doi.org/10.1016/j.jenvman.2015.08.045

[10] Kuronuma, T., Hashimoto, S., Ishihara, T., Yoshioka, T. and Watanabe, H. (2014) Temporal Change about Media and Quantification of the Carbon Dioxide Fixation in the Rooftop Lawn. Journal of the Japanese Society of Revegetation Technology, 40, 20-24. https://doi.org/10.7211/jjsrt.40.20

[11] Van Woert, N., Rowe, D.B., Andresen, J.A., Rugh, C.L. and Xian, L. (2005) Watering Regime and Green Roof Substrate Design Affect Sedum Plant Growth. HortScience, 40, 659-664.

[12] Gravatt, D.A. and Martin, C.E. (1992) Comparative Ecophysiology of Five Species of Sedum (Crassulaceae) under Well-Watered and Drought-Stressed Conditions. Oecologia, 92, 532-541. https://doi.org/10.1007/BF00317845

[13] Lee, H.S.J. and Griffiths, H. (1987) Induction and Repression of CAM in Sedum telephium L. in Response to Photoperiod and Water Stress. Journal of Experimental Botany, 38, 834-841. https://doi.org/10.1093/jxb/38.5.834

[14] Sayed, O.H. (2001) Crassulacean Acid Metabolism 1975-2000, a Check List. Photosynthetica, 39, 339-352. https://doi.org/10.1023/A:1020292623960

[15] Butler, C. and Orians, C.M. (2011) Sedum Cools Soil and Can Improve Neighboring Plant Performance during Water Deficit on a Green Roof. Ecological Engineering, 37, 1796-1803. https://doi.org/10.1016/j.ecoleng.2011.06.025

[16] Durhman, A.K., Rowe, D.B. and Rugh, C.L. (2006) Effect of Watering Regimen on Chlorophyll Fluorescence and Growth of Selected Green Roof Plant Taxa. HortScience, 41, 1623-1628.

[17] Lambers, H., Cambridge, M.L., Konings, H. and Pons, T.L. (1989) Causes and Con- 
sequences of Variation in Growth Rate and Productivity of Higher Plants. SPB Academic Publishing, The Hague.

[18] Hunt, R. (1986) Plant Growth Curves: The Functional Approach to Plant Growth Analysis. Edward Arnold, London.

[19] Schneider, C.A., Rasband, W.S. and Eliceiri, K.W. (2012) NIH Image to ImageJ: 25 Years of Image Analysis. Nature Methods, 9, 671-675. https://doi.org/10.1038/nmeth.2089

[20] Adamsen, F.G., Pinter, P.J., Barnes, E.M., LaMorte, R.L., Wall, G.W., Leavitt, S.W. and Kimball, B.A. (1999) Measuring Wheat Senescence with a Digital Camera. Crop Science, 39, 719-724. https://doi.org/10.2135/cropsci1999.0011183X003900030019x

[21] Evans, G.C. (1972) The Quantitative Analysis of Plant Growth. Blackwell Scientific Publications, Oxford.

[22] Kuronuma, T. and Watanabe, H. (2016) Physiological and Morphological Traits and Competence for Carbon Sequestration of Several Green Roof Plants under a Controlled Environmental System. Journal of the American Society for Horticultural Science, In Press.

[23] Poorter, H. and Nagel, O. (2000) The Role of Biomass Allocation in the Growth Response of Plants to Different Levels of Light, $\mathrm{CO}_{2}$, Nutrients and Water: A Quantitative Review. Australian Journal of Plant Physiology, 27, 595-607. https://doi.org/10.1071/PP99173_CO

[24] Pooter, H. and Remkes, C. (1990) Leaf Ratio and Net Assimilation Rate of 24 Wild Species Differing in Relative Growth Rate. Oecologia, 83, 553-559. https://doi.org/10.1007/BF00317209

[25] Pooter, H., Remkes, C. and Lambers, H. (1990) Carbon and Nitrogen Economy of 24 Wild Species Differing in Relative Growth Rate. Plant Physiology, 94, 621-627. https://doi.org/10.1104/pp.94.2.621

\section{Submit or recommend next manuscript to SCIRP and we will provide best service for you:}

Accepting pre-submission inquiries through Email, Facebook, LinkedIn, Twitter, etc. A wide selection of journals (inclusive of 9 subjects, more than 200 journals)

Providing 24-hour high-quality service

User-friendly online submission system

Fair and swift peer-review system

Efficient typesetting and proofreading procedure

Display of the result of downloads and visits, as well as the number of cited articles

Maximum dissemination of your research work

Submit your manuscript at: http://papersubmission.scirp.org/

Or contact ajps@scirp.org 